\title{
Theoretical and methodological aspects of separatism as a political phenomenon
}

UDC 32.323.01:323.173

DOI https://doi.org/10.24195/2414-

9616.2021-2.11

Khevtsuriani Amiran

Doctor of International Relations,

Professor, Academician,

Georgian Technical University

Kostova str., 77 ,

Tbilisi, Georgia

Kharchilava Lili

Doctoral Student at the Faculty of Law

and International Relations

Georgian Technical University

Kostova str., 77 ,

Tbilisi, Georgia

\begin{abstract}
Modern society is entering an era characterized by the emergence of new challenges: progressive nationalism, terrorism, religious intolerance, as well as increasingly asserting itself political separatism. The latter showed its destructive potential at the end of the 20th century during the collapse of a number of states in Asia, Africa and Europe, which for a long time existed as a single statehood. In the modern world, a number of ethnically heterogeneous states face ethnic challenges that take the form of ethnopolitical conflicts and even internal (separatist) wars. Thus, this phenomenon goes beyond national and regional security problems and acquires an international character.

The study of the phenomenon of separatism is complicated by the fact that both in science and practical politics, it has a clearly expressed emotional context, since both the subjects of an open political struggle and participants scientific discourse operate with fundamental values that affect the ethnic, cultural or national identity of large social groups. Therefore, separatism seems to be one of the most difficult problems in the field of political and conflictological studies, since it is associated with a serious threat to the existence of the integrity of the state and its sovereignty.

By the nature of any phenomenon (including separatism), we mean the sources from which it was formed. Such sources are various kinds of factors: internal and external; subjective and objective. The key essential characteristic of separatism is the tendency to separate groups within integral national formations in connection with the actualization of territorial and ethnic identity. Thus, separatism is associated with the emotional and sacred component of the mass consciousness and with the attributes of the nation state.
\end{abstract}

Key words: separatism, irredentism, regionalism, independence, federalism, superethnos.
Introduction. In the works of most scholars throughout the history of political thought, the essence of separatism was considered in the context of its negative consequences for the integrity of state borders and the preservation of sovereignty.

According to the American political scientist D. Horowitz, separatism is active actions to withdraw a territory and the population living on its territory from a larger state, of which it is a part. The researcher pays attention, first of all, to the legal side of the issue, placing at the forefront the problem of preserving/ violating sovereignty, which, as a rule, is spelled out in the Constitution. Separatism always turns out to be closely related to the concept of "sovereignty", since it presupposes a violation of the territorial integrity of the state as its attributive property. It was in the change in ideas about the essence and content of sovereignty that, according to the author, the greatest contradictory opinions on the problems of nation-state building were manifested [2, p. 42].

Concept of "separatism" vs "secession". The "generic"term of separatismis the conceptofsecession. The diversity of the phenomenon of separatism has led to the fact that the problem of secessionism, as a political and civil phenomenon, "drowned" in numerous works devoted to the description of various movements, types and forms of separatism. Often in the political science literature you can find the use of the term "separatism" and "secessionism" as synonyms. Perhaps, this can be called true only in a legal vein, when direct secession (separatism) takes a legally enshrined form - secession. From the point of view of political processes and the mood of civil society, everything is a little more complicated.

The significant number of forms of secession that can be exploited by territories within a country is a growing problem faced by many European countries. Secession is no longer just a legal possibility of leaving the composition, it is the result of the alienation of society and the state, which has become a deep contradiction. Most modern scholars emphasize the unproductiveness of secession as a tool for overcoming the fundamental problem of the relationship between society and the state $[3$, p. 66]. In general, the phenomenon of political alienation is a consequence of the formation of any state [4], which, by redistributing resources, realizes the right to a monopoly on violence based on unlimited amount of seized public resources. The measure of civil alienation is determined by the ratio of the actions of power to the total number of actions of individuals.

In science separatism is most often called the desire of individual parts of the state to secede, to stand apart as a new state or autonomous entity on national, religious or linguistic grounds [5, p. 398].

Due to the complexity of the nature of separatism, it can be considered in different aspects: legal (legal), political, ideological, socio-cultural, etc. From a legal point of view, separatism is a certain purposeful, legally regulated behaviour, a special legally significant activity. Some scholars (for example, S. Huntington) interpret separatism precisely as illegal activity aimed 
at the withdrawal of autonomy from a sovereign state [6, p. 132].

Taking into account the fact that most modern states are polystructural and polyethnic, the presence and strengthening of ethnic contradictions becomes an objective prerequisite for the formation of separatist sentiments and actions. They are usually based on sociocultural, linguistic, socio-economic disproportions and even ecological differences, perceived by the ethnic minority as a manifestation of discrimination on the part of the government (the so-called "Centre"), which protects the interests of only the ethnic majority (or "superethnos"). Political discrimination as one of the conditions for the emergence of separatist movements and sentiments usually manifests itself in the fact that, unlike the dominant majority, a small ethnic unit is deprived or limited in political rights. The situation is aggravated by economic discrimination.

The range of reasons and prerequisites for the emergence of separatism is very wide. It is worth highlighting the fact that American and British researchers, who have accumulated the most experience in studying this phenomenon, focus on the socio-economic factor in the formation of separatist movements. As a specific factor, there are intergroup relations that develop between ethnic groups with different levels of socio-economic development, which largely determine the behaviour of these groups.

In this vein, theoretical grounds are put forward that the more economically developed, richer regions show a greater tendency towards secession. Arguments in favour of this position come, for the most part, from the study of a number of cases of ethnic separatism in the post-Soviet space.

Among researchers who have studied similar phenomena in other parts of the world, mainly in Asia and Africa, the opposite opinion prevails, however, that the richer regions prefer to remain part of the ethno-federal system, since in this case they have much more benefits for yourself. From this point of view, the poor regions are the most exploited part of the country, and they, of course, are more likely to raise the banner of secession at the first opportunity. There is a rather serious theoretical contradiction that requires at least a partial resolution.

Theoretical provisions based on the so-called "dilemma of ethnic security", suggest that the most economically developed ethnic regions of a multinational state will be the first candidates for secession from the federation [7].

States in which national minorities are concentrated on one territory stand out in the theory of security dilemma as an independent case, since there is a potentially more convenient way to resolve this dilemma: instead of escalating ethnic tension by creating mutual threats or cultivating mutual fears, any ethnic group can impose the main hopes of avoiding such threats to withdraw from the ethnofederal system.

Forms of contemporary separatism. Separatism can be carried out in different forms (ideas, actions, slogans), remaining unchanged in ideological content and preserving the nature of an illegal or at least legally ambiguous phenomenon. Moreover, in the case of an obvious antisocial and illegal nature of this phenomenon, we have every right to characterize its form and the actions of supporters of separatist ideas as extremist, since the very fact that a certain behavioural form is illegal includes the "extreme" ways and methods of achieving the designated targets [8].

Today in the world political and territorial isolation is increasingly becoming the cause of extremist activity. The essence of modern extremist movements characterizes the attitude towards "their" isolated territory, which is the material basis for the functioning of a social community that makes it possible to identify as separatist most of them [9].

The main element of any separatist conflict remains an identity crisis, which consists in a change in the national, political and religious self-identification of the population, an increase in the role of nationalist groups and organizations and their political activity [10].

In this work, separatism is defined as a political movement that arises in geographically heterogeneous states and is aimed at the withdrawal of a separate territory from an integrated state to create a new independent state (that is, a secession that will result from this process) or inclusion in another state (Irredentism).

Along with separatism, such forms of disintegration as regionalism and autonomy are distinguished.

Separatism is the result of a disintegration process that takes place in an extremely dynamic and active mode. Note that autonomy and regionalism do not entail the separation of an autonomous territory from a single state and usually act as the first stages of the disintegration process.

Another stage in the disintegration process is regionalism. It is characterized by the dissatisfaction of certain regional and ethnic groups with their position and their desire to recognize the cultural isolation and economic independence of the region, the struggle for reforms, but within the existing state structure [11, p. 23].

Autonomy is an appeal by the inhabitants of a territory to the idea of recognizing it as autonomy, to the consolidation of specific rights and privileges in the management rights of any part of the state in the main law of the country and other normative legal acts. Autonomy differs from separatism by the struggle for the recognition of the region's rights to self-government within the framework of existing legislation, without the requirements of independence, and from regionalism - by a wider set of requirements for economic, socio-cultural and political independence [11, p. 24]. 
It would seem that it is easiest to typologize separatism by its nature and ideological colouring: religious, ethnic, sociolinguistic. However, many of these components turn out to be closely intertwined and represent a "tangle of contradictions". Although most often you can find precisely the ethnic and religious types of separatism, the subjects of which are the corresponding minorities. At the same time, any type of separatism, regardless of its nature, is based on a misunderstood principle of self-determination, when any ethnic (confessional) or socio-cultural (linguistic) community must have its own state-formalized territory. In documents of international law, in the laws of various states, in political theory, such there is no interpretation of the principle of the right of nationalities and ethnic groups to self-determination.

In international legal documents, the right to self-determination is understood as the right not of national-ethnic groups, but of territorial communities, to build their own system of government, taking into account the democratically expressed will of the population of the territory and, naturally, without infringing on the political, social and cultural rights of the rest of the population, relying on recognition the existing system of statehood. First of all, for national groups, self-determination is the realization of their rights to actively participate in various social and political processes, to form their own, unique civic associations that most effectively solve local problems [12]

Often national - ethnic separatism intensifies in the context of a socio-economic crisis, rising unemployment, crime, widening gap between the poor and the rich, increasing differentiation of citizens, in the course of a tough struggle for power. All these factors are used by national ethnic groups or regional elites as a tool to put pressure on the central government and often turn into violent conflict.

The tendencies of ethnic separatism, due to the special character of ethnic solidarity, the so-called "ethnic favouritism" or nepotism, poses a great threat to the country's integrity. People's tendencies to favour vital groups, that is, relatives, family, and act at the same time with them in conflict situations [13, p. 17].

Encroachment on the sovereignty of the state by any groups using the ideas of separatism is another important aspect of the analysis of this phenomenon. The aspect is largely legal. Modern researchers believe that the current state has power over the territory outlined by the established boundaries. Thus, the dominant factor in relations between the state and national groups wishing to secede is the principle of sovereignty over a certain territory, or, in other words, the principle of territoriality.

Various national groups constantly refer to the right of nations to self-determination, which is enshrined in some of the most important international legal acts.
However, the right of nations to self-determination is not at all the basis of the right to secede from the state. The absence of a universally valid right to self-determination leads to secession, which, thus, comes into direct conflict with the international legal foundations of the state's territorial sovereignty. The consequence of this, most likely, would be the endless disintegration of states, accompanied by resettlement, if such a right existed and was consistently applied [14, p. 21].

Religious separatism should be especially noted in this context. Religious separatism, in contrast to ethnic separatism, is predetermined by ideological or religious attitudes towards the creation of territorial autonomy on a confessional basis (for example, the Protestant "ultra" in Northern Ireland, the religious sect "Aum Senrikyo" in Japan, the Islamic movement "Muslim Brotherhood" in the Middle East, etc.) or an independent theocratic state. In recent years, the problem of Islamic separatism has become much more urgent. It's like with external influence from states and organizations interested in destabilizing the political situation on the territory of a particular state (material support of anti-government organizations, export of extremist views, "warming up" separatism, etc.) [15, p. 16].

In the event of the emergence and escalation of interreligious and interethnic conflicts, the dominant role in most cases belongs to extremist movements within the framework of religious and national-ethnic separatism.

Conclusions. It is important to understand the principle of self-determination as a special political process, during which it is necessary to take into account the complex nature of the relationship between rights and obligations, provided that this principle is implemented. In our opinion, in modern conditions it should not be reduced to the limited format "one state for one nation". In this paper we are of the opinion that this principle is extremely destructive, because:

firstly, the issue of the contradiction between the principles of state sovereignty, which implies the unity and indivisibility of the territory and the principle of nationality, which implies the territorial isolation of the people/peoples, remains unresolved;

secondly, there is still no single approach to the criteria for determining the possibility of selfdetermination and further independent existence and development.

To date, secession is the only developed legal condition for self-determination, which implies:

the right to exercise secession must be enshrined in the current Constitution of the country. But at the same time, the very provisions of the Constitution or the status of the subject (territory) cannot serve as a basis for secession, since they may be inconsistent/contrary to the norms of the national Constitution, the constitution can recognize the right to self-determination only under the federal structure of the state. In other forms 
of administrative-territorial structure, the right to secession is not granted;

the right of an ethnic group to self-determination should be exercised only in certain, legally established forms. At the same time, there should be a guarantee of the observance of the interests of this ethnos, as well as all other ethnic groups that previously formed a single state with it. The observance of universally recognized human rights (of the country's population as a whole) also remains obligatory;

in the event of a secession, it is necessary to objectively assess the feasibility of the chosen form of self-determination, especially if full separation/ secession from the state is assumed.

Another important specificity of secession is that it is possible only under federalism. In this case, the right to exercise secession is recognized only if the federation was based on the national-territorial principle with the right of nations to self-determination. Only if the above conditions are met, secession can be recognized as the optimal legal form of territorial separation. At the same time, it is worth paying attention to the fact that territorial and political isolation is a narrower concept than the ethno-religious selfdetermination of the people.

\section{BIBLIOGRAPHY:}

1. Тишков В.А. Реквием по этносу: Исследования по социально-культурной антропологии. Москва : Наука. 2003. 544 с.

2. Горовиц Д. Ирредентизм, сепаратизм и самоопределение. Национальная политика в Российской Федерации. Москва : Наука, 1993. С. 147.

3. Фарукшин М.Х. Этничность и федерализм. Казань. 2013. С. 49-106.

4. Макаренко В.П. Теория сецессии: посылки, аргументы и следствия. Вестник Московского универсuтema: Сер. 18: Социология и политология. 2006. № 2. C. 17-41.

5. Политическая энциклопедия. В 2-х томах. Т. 2. Москва : Мысль, 1999. С. 398-399.

6. Хантингтон С. Столкновение цивилизаций. Москва : «Издательство АСТ», 2003. С. 234.

7. Денисова Г.С. Этнический фрактор в чеченском кризисе. Научная мысль Кавказа. № 3. 1996. С. 54-60.

8. Политическая энциклопедия. В 2-х томах. Т. 2. Москва : Мысль, 1999. С. 399.

9. Правовые основы противодействия экстремистской деятельности : материалы Всероссийской научно-практической конореренции (11 февраля 2011 года). Тюмень : Вектор Бук, 2011. С. 89.

10. Болотникова О.Р. Территориальная целостность государств и право наций на самоопределение: возможен ли компромисс? Актуарные проблемы мировой политики и мировой экономики. Москва : Издательство Перо, 2010. С. 33.

11. Лубский А.В. Глобализация и регионализация: к методологии исследования. Глобализация и регионализация в современном мире : материалы международной научной консеренции. Ростовна-Дону : Социально-гуманитарные знания, 2002. C. 23.
12. Байрамов И.М. Проблема этнического сепаратизма в социальной психологии. Баку, ТолГУ, 2011. C. 2

13. Ванханен Т. Этнические конфрликты: их биологические корни в этническом фраворитизме. Москва : Кучково поле, 2014

14. Бабкин И.О. Феномен этнического сепаратизма : авторесерат диссертации на соискание ученой степени кандидата политических наук. Ставрополь, СГУ, 2002.

15. Поляков А.Е. Сепаратизм как форма политико-правовой девиации: теоретико-правовой аспект : автореферат диссертации на соискание ученой степени кандидата юридических наук. Санкт-Петербург : Изд-во Санкт-Петербургского государственного ун-та, 2003.

\section{REFERENCES}

1. Tishkov, V.A. (2003). Rekviem po jetnosu: Issledovanija po social'no-kul'turnoj antropologii. Moscow : Nauka, 544

2. Gorovic, D. (1993). Irredentizm, separatizm i samoopredelenie. Nacional'naja politika $v$ Rossijskoj Federacii. Moscow: Nauka, 147.

3. Farukshin, M.H. (2013). Etnichnost' i federalizm. Kazan. 49-106.

4. Makarenko, V.P. (2006). Teorija secessii: Posylki, argumenty i sledstvija. Vestnik Moskovskogo universiteta: Ser. 18: Sociologija i politologija. No. 2, 17-41.

5. Politicheskaja jenciklopedija. (1999). V 2-h t. T. 2. Moscow : Mysl, 398-399.

6. Hantington, S. (2003). Stolknovenie civilizacij. Moscow: "Izdatelstvo ACT", 234.

7. Denisova, G.S. (1996). Jetnicheskij faktor v chechenskom krizise. Nauchnaja mysl Kavkaza. No. 3. 54-60.

8. Politicheskaja jenciklopedija. (1999). V 2-h t. T. 2. Moscow : Mysl, 399.

9. Pravovye osnovy protivodejstvija jekstremistskoj dejatel'nosti: Materialy Vserossijskoj nauchnoprakticheskoj konferencii (11 fevralja 2011 goda) (2011). Tjumen : Vektor Buk, S. 89.

10. Bolotnikova, O.R. (2010). Territorial'naja celostnost' gosudarstv i pravo nacij na samoopredelenie: vozmozhen li kompromiss? Aktuarnye problemy mirovoj politiki i mirovoj jekonomiki. Moscow : Izdatelstvo Pero, 33.

11. Lubskij, A.V. (2002). Globalizacija i regionalizacija: k metodologii issledovanija. Globalizacija i regionalizacija v sovremennom mire: Materialy mezhdunarodnoj nauchnoj konferencii. Rostov-na-Donu: Socialno-gumanitarnye znanija, 23

12. Bajramov, I.M. (2011). Problema etnicheskogo separatizma v social'noj psihologii. Baku, TolGU, 2.

13. Vanhanen, T. (2014). Etnicheskie konflikty: ih biologicheskie korni v etnicheskom favoritizme. Moscow : Kuchkovo pole.

14. Babkin, I.O. (2002). Fenomen jetnicheskogo separatizma: Avtoreferat dissertacii na soiskanie uchenoj stepeni kandidata politicheskih nauk. Stavropol : SGU.

15. Poljakov, A.E. (2003). Separatizm kak forma politiko-pravovoj deviacii: Teoretiko-pravovoj aspekt: Avtoreferat dissertacii na soiskanie uchenoj stepeni kandidata juridicheskih nauk. Sankt-Petersburg: Izd-vo SanktPeterburgskogo gosudarstvennogo un-tu. 


\section{Теоретичні та методологічні аспекти сепаратизму як політичного явища}

Хевцуріані Аміран

$\mathrm{PhD}$ з міжнародних відносин, професор, академік,

Грузинський технічний університет

вул. Костава,

77, Тбілісі, Грузія

\section{Харчилава Лілі}

аспірант фракультету права

та міжнародних відносин

Грузинського технічного університету

вул. Костава, 77 ,

Тбілісі, Грузія
Сучасне суспільство вступає в епоху, що характеризується появою нових викликів: прогресивного націоналізму, тероризму, релігійної нетерпимості, а також політичного сепаратизму, що поширюється дедалі більше. Останній продемонстрував свій руйнівний потенціал наприкінці XX століття під час розпаду низки держав в Азії, Асриці та Європі. У сучасному світі низка етнічно неоднорідних держав стикаються з етнічними проблемами, що набувають фрорм етнополітичних конфрліктів і навіть внутрішніх (сепаратистських) війн. Таким чином, че явище виходить за рамки проблем національної та регіональної безпеки та набуває міжнародного характеру.

Дослідження явища сепаратизму ускладнюється тим, що як у науці, так і в практичній політиці че явище має чітко виражений емоційний контекст, оскільки як суб'єкти відкритої політичної боротьби, так і учасники наукового дискурсу оперують фунндаментальними цінностями, що корелюють з етнічною, культурною або національною ідентичністю великих соціальних груп. Сепаратизм видається однією з найскладніших проблем у галузі політичних досліджень, оскільки він пов'язаний із серйозною загрозою існуванню цілісності держави та ї суверенітету.

Під природою будь-якого явища (включаючи сепаратизм) ми маємо на увазі джерела, з яких воно походить. Такими джерелами є різного роду фактори: внутрішні та зовнішні; суб'єктивний та об'єктивний. Ключовою суттєвою характеристикою сепаратизму є тендениія до відокремлення груп у рамках цілісних національних утворень у зв'язку з актуалізацією територіальної та етнічної ідентичності. Отже, сепаратизм пов'язаний з емоційним та сакральним складниками масової свідомості та з атрибутами національної держави.

Ключові слова: сепаратизм, іредентизм, регіоналізм, незалежність, фредералізм, суперетнос. 